\title{
Integration of Membrane Distillation with solar photo-Fenton for purification of water contaminated with Bacillus sp. and Clostridium sp. spores
}

Ruiz-Aguirre, A., Polo-López, M. I., Fernandez-Ibanez, P., \& Zaragoza, G. (2017). Integration of Membrane Distillation with solar photo-Fenton for purification of water contaminated with Bacillus sp. and Clostridium sp. spores. Science of the Total Environment, 595, 110-118. https://doi.org/10.1016/j.scitotenv.2017.03.238

Link to publication record in Ulster University Research Portal

\section{Published in:}

Science of the Total Environment

Publication Status:

Published online: 15/04/2017

DOI:

10.1016/j.scitotenv.2017.03.238

\section{Document Version}

Author Accepted version

\section{General rights}

Copyright for the publications made accessible via Ulster University's Research Portal is retained by the author(s) and / or other copyright owners and it is a condition of accessing these publications that users recognise and abide by the legal requirements associated with these rights.

\section{Take down policy}

The Research Portal is Ulster University's institutional repository that provides access to Ulster's research outputs. Every effort has been made to ensure that content in the Research Portal does not infringe any person's rights, or applicable UK laws. If you discover content in the Research Portal that you believe breaches copyright or violates any law, please contact pure-support@ulster.ac.uk. 


\title{
Integration of Membrane Distillation with solar photo-Fenton for purification of water contaminated with Bacillus sp and Clostridium sp spores
}

\author{
A. Ruiz-Aguirre ${ }^{\mathrm{a}}$, M. I. Polo-López ${ }^{\mathrm{b}}$, P. Fernández-Ibáñez ${ }^{\mathbf{c}}$, G. Zaragoza ${ }^{\mathbf{b}^{*}}$ \\ ${ }^{a}$ Universidad de Almería - CIESOL, Ctra. Sacramento, s/n, 04120 La Cañada de San Urbano, Almería, Spain \\ ${ }^{b}$ CIEMAT-Plataforma Solar de Almería, Ctra. de Senés s/n, 04200 Tabernas, Almería, Spain \\ ${ }^{c}$ Nanotechnology and Integrated BioEngineering Centre, School of Engineering, University of Ulster, \\ Newtownabbey, Northern Ireland, BT37 0QB, United Kingdom. \\ *Corresponding Author, guillermo.zaragoza@psa.es
}

\section{STOTEN-D-17-01065-R1}

Revised manuscript submitted to Science of the Total Environment

March 25, 2017 


\section{$1 \quad$ Abstract}

2 Although Membrane Distillation (MD) has been extensively studied for desalination, it has 3 other applications like removing all kinds of solutes from water and concentrating non-volatile 4 substances. MD offers the possibility of producing a clean stream while concentrating valuable 5 compounds from waste streams towards their recovery, or emerging contaminants and 6 pathogens present in wastewater in order to facilitate their chemical elimination. This paper analyses the elimination of bacterial spores from contaminated water with MD and the role of

$8 \mathrm{MD}$ in the subsequent treatment of the concentrate with photo-Fenton process. The experiments 9 were performed at Plataforma Solar de Almería (PSA) using a plate and frame bench module 10 with a Permeate Gap Membrane Distillation (PGMD) configuration. Tests were done for two 11 different kinds of spores in two different water matrixes: distilled water with $3.5 \mathrm{wt} \%$ of sea 12 salts contaminated with spores of Bacillus subtilis (B. subtilis) and wastewater after a secondary 13 treatment and still contaminated with Clostridium sp spores. An analysis of the permeate was 14 performed in all cases to determine its purity, as well as the concentrated stream and its further 15 treatment in order to assess the benefits of using MD. Results showed a permeate free of spores 16 in all the cases, demonstrating the viability of MD to treat biological contaminated wastewater 17 for further use in agriculture. Moreover, the results obtained after treating the concentrate with 18 photo-Fenton showed a shorter treatment time for the reduction of the spore concentration in the 19 water than that when only photo-Fenton was used. 
2 Water scarcity is one of the main challenges of the XXI century that many societies around the world are already facing. Throughout the last century, use and consumption of water grew at twice the rate of population growth and, although there is not water scarcity globally, the number of regions with chronic levels of water shortages is increasing. Water scarcity is not only a natural phenomenon, but is also caused by human action. Nowadays, there is enough freshwater to supply people who inhabit the planet, however, it is distributed unevenly, wasted, polluted and unsustainably managed [1]. Due to the development of industry and agriculture together with the rise of population and living standard, water consumption is increasing [2]. Agriculture consumes at least $70 \%$ of water in the world. The use of wastewater in agriculture is being increasingly proposed, since it could have agronomic and economic benefits [3]. On one hand, irrigation with wastewater may increase the available water supply and so allow preserving better quality supplies for other uses [4]. On the other hand, the fertilizer content of many kinds of wastewater can be an advantage for agricultural use [5]. According to FAO, wastewater effluent from domestic sources may contain all the nitrogen as well as most of the phosphorus and potassium usually required for agricultural crop production [6]. However, the use of wastewater has several risks for public health $[7,8]$. Wastewater, especially domestic wastewater contains pathogens that can cause different diseases, as they contain fecal pathogens. The most common enteric microorganisms found in such wastewaters are bacteria, viruses, protozoa and helminthes [9]. Therefore, the reuse of wastewater for purposes such as agriculture makes necessary the treatment of the water before their use [10]. Some conventional treatments of disinfection including chlorination and ozonation, generate toxic disinfection byproducts that make necessary searching for innovative technologies for pathogens removal [11]. An alternative to conventional disinfection systems is the use of advanced oxidation technologies, based on the generation of oxidant radicals which attack indistinctly organic matter and water microorganisms [12]. Advances oxidation processes (AOPs) have been shown successful for the removal of organic contaminants $[12,13]$. AOPs are based on the generation of hydroxyl radicals, which are highly oxidant $\left(\mathrm{E}^{0}=2.8 \mathrm{~V}\right)$. They are highly reactive without chemical selectivity. Among AOPs, photo-Fenton is considered as one of the most successful processes due to its high generation rate of radicals in ideal conditions (optimized concentrations of $\mathrm{Fe}$ and $\mathrm{H}_{2} \mathrm{O}_{2}$, and $\mathrm{pH}$ close to 3) and effectiveness in organic pollutants degradation $[14,15]$. It has also been proven recently as a good option for wastewater disinfection [16-21]. Photo-Fenton process comprehends a complex series of chemical reactions that all together represent a catalytic process that converts $\mathrm{Fe}$ (III) to $\mathrm{Fe}$ (II) and vice versa and generates hydroxyl radicals, while $\mathrm{H}_{2} \mathrm{O}_{2}$ and UV-vis light must be present [22]. The process can be summarized as follows. 
3 Membrane Distillation (MD) is an emerging technology that consists in a thermal process in 4 which only vapour molecules pass through a porous hydrophobic membrane. The feed is in direct contact with the surface of the membrane but it does not penetrate thanks to the hydrophobic nature of the membrane. The driving force of the process is the vapour pressure difference through the membrane. This can be established by increasing the temperature of the

8 feed at one side of the membrane, which increases its vapour pressure and therefore establishes

9 a gradient across the membrane [23-25]. MD presents a number of advantages that make it competitive in more applications. The most important advantages of MD are: I) normally, a pretreatment of feed is not necessary to enlarge the membrane life; II) the good quality of the permeate is independent from the concentration of the feed; III) possibility of treating corrosive and acid effluents [26]. These positive characteristics make MD suitable for production of ultrapure water, desalination of brines, removal of dyes and treatment of textile wastewater, concentration of acids and corrosive substances, juice and whey concentration in food industry, and finally treating water contaminated with pathogens [27]. A previous article [28] showed a first demonstration of the removal of two types of microorganisms, i.e. Fusarium solani spores and Escherichia coli (E. coli), in water using MD to obtain an effluent free of pathogens. The main conclusion was that thermal increase by MD provoked a complete abatement of Fusarium sp and E. coli within the module, as they are quite sensitive to $\mathrm{T}>50^{\circ} \mathrm{C}[29,30]$ and $\mathrm{MD}$ temperatures reach up to $80^{\circ} \mathrm{C}$. Although E. coli is frequently used as indicator of fecal contamination, in this case new thermo-tolerant microorganisms are required as indicator for a deep assessment of MD for wastewater disinfection. As this work aims at the disinfection of wastewater using MD followed by solar photo-Fenton, the selected microorganism should be not only thermo-tolerant but also highly resistant to disinfection processes commonly used, i.e. chlorine, ozone or UVC. This is the case of some spore forming bacteria; Bacillus and Clostridium species are among the most resistant microorganisms known [31]. Bacterial spores are very resistant to a variety of environmental conditions, including heat, radiation and many toxic chemicals [32-36]. Wet heat is the most commonly used method to inactivate spores. Bacillus subtillis (B. subtilis) is a non-pathogenic bacterium, easy to culturing and molecular genetic manipulation of some strains. This has made B. subtilis a good model microorganism for both lab-scale and full-scale tests. Clostridium $\mathrm{sp}$ is a pathogen that causes infection diseases, constituting a health risk for humans and animals. It lives in different habitats such as soils and water. Clostridium sp spores and in general spores of sulphite-reducing Clostridia 
1 (SRC), are suggested as indicator of oocysts of Cryptosporidium sp and other highly resistant

2 pathogens [37].

3 Inactivation of highly resistant microorganisms in water has a special scientific and 4 technological interest with health and environmental implications. In response to these needs, 5 the objective of this study was to investigate the role of MD in the treatment of two different matrix water contaminated by spores of gram- positive bacteria: salty water inoculated with $B$. subtilis spores obtained after a sporulation process carried out in the laboratory and treated urban wastewater naturally contaminated with Clostridium sp spores. Namely, to test if the permeate production is free of microorganisms and to study if MD influences the further treatment of the rejected feed. So, the remaining feed was treated with photo-Fenton at $\mathrm{pH} 3$ due to the high resistance of the spores to conventional disinfection treatment.

\section{Materials and Methods}

\subsection{Water types}

The MD experiments were carried out in two types of water, salty water and real urban wastewater effluents (UWW). The first approach aimed at the study of the functioning of MD modules for removal of spores of $B$. subtillis in synthetic salty water. The second approach was done using UWW to demonstrate the capability of MD at pilot scale for purification of a real and complex wastewater to produce a highly pure stream and naturally occurring Clostridium sp spores were monitored in this case.

The experiments with saline water were done with distilled water (conductivity: $0.74 \mu \mathrm{S} / \mathrm{cm}$ and organic carbon: $0.5 \mathrm{mg} / \mathrm{l}$ ) adding $3.5 \mathrm{wt} \%$ of sea salts to simulate the standard ocean salinity. Spores of $B$. subtilis were used in this water matrix as they represent a very high resistant biological agent to be inactivated and furthermore they has been isolated from marine invertebrates and detected in seawater of different areas of Pacific Ocean [38]. The salts also served as an indicator of possible wetting on the MD, which would affect the salinity of the permeate. Sea salts used in this study came from raw material from the saltworks of Cabo de Gata, Almería, Spain. In general, the main salt ions that make up $99.9 \%$ are shown in the following table (Table 1).

Table 1. Main salt ions of seawater.

\begin{tabular}{cc}
\hline Cations & Concentration $(\mathrm{mg} / \mathrm{l})$ \\
\hline $\mathrm{Na}^{+}$ & $9,600-11,700$ \\
$\mathrm{Mg}^{2+}$ & $1,025-1,400$
\end{tabular}




\begin{tabular}{cc}
$\mathrm{Ca}^{2+}$ & $375-525$ \\
$\mathrm{~K}^{+}$ & $350-500$ \\
$\mathrm{Sr}^{2+}$ & $12-14$ \\
\hline Anions & Concentration $(\mathrm{mg} / \mathrm{l})$ \\
\hline $\mathrm{Cl}^{-}$ & $17,500-21,000$ \\
$\mathrm{SO}_{4}{ }^{2-}$ & $2,425-3,000$ \\
$\mathrm{HCO}_{3}^{-}$ & $120-170$ \\
$\mathrm{Br}^{-}$ & $59-120$ \\
$\mathrm{BO}_{3}^{-}$ & $6-27$ \\
$\mathrm{~F}^{-}$ & 1 \\
\hline
\end{tabular}

2

3 Freshly UWW from the urban wastewater treatment plant of Almeria was also used to study the 4 evolution of the concentration of Clostridium sp spores after MD and photo-Fenton processes.

5 Clostridium sp spores are present naturally in the UWW, and thus the sporulation of a 6 dangerous species in the laboratory was avoided. B. subtilis was not studied in UWW because 7 this water usually contain a complex mixture of microorganisms and the medium used for the 8 detection of B. subtilis is not extremely selective, so it would be very difficult to distinguish it in 9 UWW. The chemical composition and characteristics of UWW are shown in Table 2.

Table 2. Ionic composition and physicochemical characteristics (average value during experiments) of UWW.

\begin{tabular}{cc}
\hline Cations $(\mathrm{mg} / \mathrm{l})$ & Concentration $(\mathrm{mg} / \mathrm{l})$ \\
\hline $\mathrm{Na}^{+}$ & $302 \pm 1$ \\
$\mathrm{Mg}^{2+}$ & $36 \pm 0$ \\
$\mathrm{Ca}^{2+}$ & $65 \pm 0$ \\
$\mathrm{~K}^{+}$ & $27 \pm 0$ \\
$\mathrm{NH}_{4}{ }^{+}$ & $76 \pm 1$ \\
\hline Anions $(\mathrm{mg} / \mathrm{l})$ & Concentration $(\mathrm{mg} / \mathrm{l})$ \\
\hline $\mathrm{Cl}^{-}$ & $563 \pm 1$ \\
$\mathrm{SO}_{4}{ }^{2-}$ & $108 \pm 0$ \\
$\mathrm{NO}_{2}{ }^{-}$ & $3 \pm 0$ \\
$\mathrm{NO}_{3}{ }^{-}$ & $4 \pm 0$ \\
$\mathrm{PO}_{4}{ }^{3-}$ & $21 \pm 0$ \\
$\mathrm{pH}^{-}$ & $8 \pm 0$ \\
Conductivity $(\mu \mathrm{s} / \mathrm{cm})$ & $2277 \pm 10$ \\
Turbidity $(\mathrm{NTU})$ & $12 \pm 0$ \\
$\mathrm{TC}(\mathrm{mg} / \mathrm{l})_{\mathrm{IC}(\mathrm{mg} / \mathrm{l})}$ & $116 \pm 0$ \\
E. coli $\left(\mathrm{CFU}^{-} / 100 \mathrm{ml}\right)$ & $91 \pm 0$
\end{tabular}




\begin{tabular}{cc}
$\mathrm{TC}(\mathrm{CFU} / 100 \mathrm{ml})$ & $5 \times 10^{6} \pm 1$ \\
E. faecalis $(\mathrm{CFU} / 100 \mathrm{ml})$ & $10^{3} \pm 1$ \\
Clostridium $\mathrm{sp}(\mathrm{CFU} / 100 \mathrm{ml})$ & $5 \times 10^{3} \pm 2$ \\
\hline
\end{tabular}

\subsection{Spores generation}

4 Cultures of B. subtilis ATCC 6633 (American Type Culture Collection, Manassas, Virginia, 5 USA), were generated from frozen stock by streaking onto tryptone soya agar (TSA) plate enriched with $0.25 \mathrm{mg} / \mathrm{MgSO}_{4}$ and were incubated at $37^{\circ} \mathrm{C}$ for 24 hours. Afterwards, two colonies from the incubated plate were transferred to tryptone soya broth (TSB) with $0.25 \mathrm{mg} / 1$ $\mathrm{MgSO}_{4}$ and incubated at $37{ }^{\circ} \mathrm{C}$ for $24 \mathrm{~h}$ shaking at $100 \mathrm{rpm}$. Then, dilutions of $10^{-1}$ were prepared using phosphate buffer with $20 \mathrm{mg} / 1$ of $\mathrm{MnCl}_{2}$. Afterwards, several times x $1 \mathrm{ml}$ of $10^{-}$

${ }^{1}$ dilution were plated in TSA $+0.25 \mathrm{mg} / 1 \mathrm{MgSO}_{4}$ culture medium and incubated at $37{ }^{\circ} \mathrm{C}$ for 15 days, for growing and sporulation. The plates were stored at $4{ }^{\circ} \mathrm{C}$ until use. To obtain the spore inoculum, the surface of TSA was rinsed with $10 \mathrm{ml}$ of distilled water and scraped with a spreader. This protocol was repeated four times more and the total volume of $50 \mathrm{ml}$ was poured in a $50 \mathrm{ml}$-tube. Then suspension was centrifuged at 3,000 rpm for $5 \mathrm{~min}$, and the spores were harvested and re-suspended in $10 \mathrm{ml}$ of distilled water. The described procedure resulted in a suspension of $4.7 \cdot 10^{10} \mathrm{CFU} / 100 \mathrm{ml}$ spore concentration. Finally, the spore suspension was placed in a water bath at $80{ }^{\circ} \mathrm{C}$ for 15 minutes to eliminate vegetative cells and keep spores only. Spore suspensions were diluted directly in the water sample to achieve an initial spore concentration of $10^{7} \mathrm{CFU} / 100 \mathrm{ml}$. For experiments of Clostridium sp spores, real UWW with naturally occurring Clostridium sp spores was used. The concentration of this pathogen in UWW samples was found ca. $5 \cdot 10^{3} \mathrm{CFU} / 100 \mathrm{ml}$, which it is enough to permit the monitoring of spore reduction throughout the water processes evaluated in this work, avoiding the need of adding any microbial component to the real UWW sample.

\subsection{Spores enumeration}

For B. subtilis spores, samples were taken and serially diluted (10 fold series) in distilled water and then spread on TSA $+0.25 \mathrm{mg} / 1 \mathrm{MgSO}_{4}$ media petri dishes. For last stage samples, $500 \mu \mathrm{l}$ of undiluted sample was dropped onto the agar plate for the enumeration of the colonies to reduce the detection limit of this enumeration method. The colonies were quantified after incubation at $37^{\circ} \mathrm{C}$ for $24 \mathrm{~h}$. The detection limit (DL) of this method was $200 \mathrm{CFU} / 100 \mathrm{ml}$.

For detection of Clostridium sp, water samples were cultured on sulphite polymyxin sulphadiazine (SPS, Cultimed, Panreac) agar medium at $44{ }^{\circ} \mathrm{C}$ under anaerobic conditions for $24 \mathrm{~h}$. Dilutions of samples were carried out to reach a DL of 2 CFU/100 $\mathrm{ml}$ [37]. 
2 A bench-scale module with a Permeate Gap Membrane Distillation (PGMD) configuration was

\subsection{Membrane Distillation (MD) Module}

\section{4} used for studying the behaviour of MD processes. In PGMD configuration, the permeate and the cold liquid are separated by a condensing foil creating a channel which is filled with stagnant permeate. The plate and frame module consisted of two transparent half-shells made of polycarbonate with a thickness of $20 \mathrm{~mm}$ and dimensions of $290 \times 140 \mathrm{~mm}$. The effective membrane area was $131 \mathrm{~cm}^{2}$. The active layer of the membrane was made of PTFE while the backing material was of PP. The nominal pore size and the porosity were $0.2 \mu \mathrm{m}$ and $85 \%$ respectively and the membrane thickness was $0.16 \mathrm{~mm}$. The separate channel was established using a $1 \mathrm{~mm}$ gap spacer between the membrane and the condenser channel.

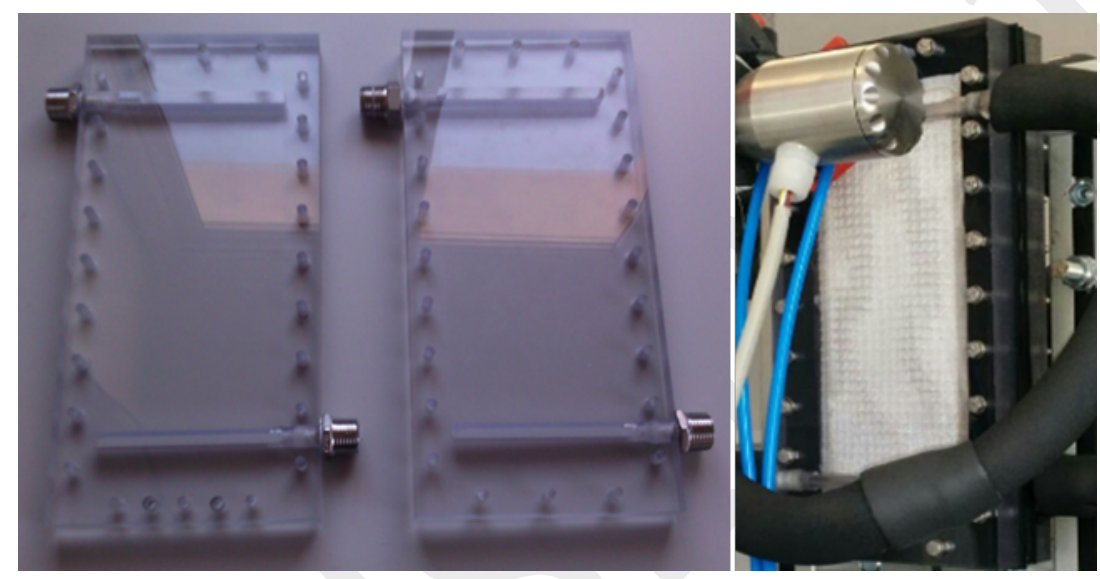

Figure 1. Evaporator and condenser shells (left) and test cell (right).

The test module was integrated into a test facility consisting of two separate hydraulic loops, one for the hot feed and one for the cooling (Figure 2). In the hot loop, the feed water was recirculated from an 801 storage tank with an electrical heater that can provide a maximum of $3 \mathrm{~kW}_{\text {th. }}$ In the cooling loop, the cold water was recirculated from another 801 storage tank connected to a compressor chiller. Finally, the permeate was collected in another tank placed on a precision balance to register continuously the mass of permeate. Four encapsulated Pt100 temperature sensors were positioned at the evaporator inlet, evaporator outlet, condenser inlet and condenser outlet of the test module. The volume flow rates were measured by different flow meters. The feed flow rate was measured by a magnetic inductive flow meter while the cooling flow rate was measured by a variable area flowmeter. 


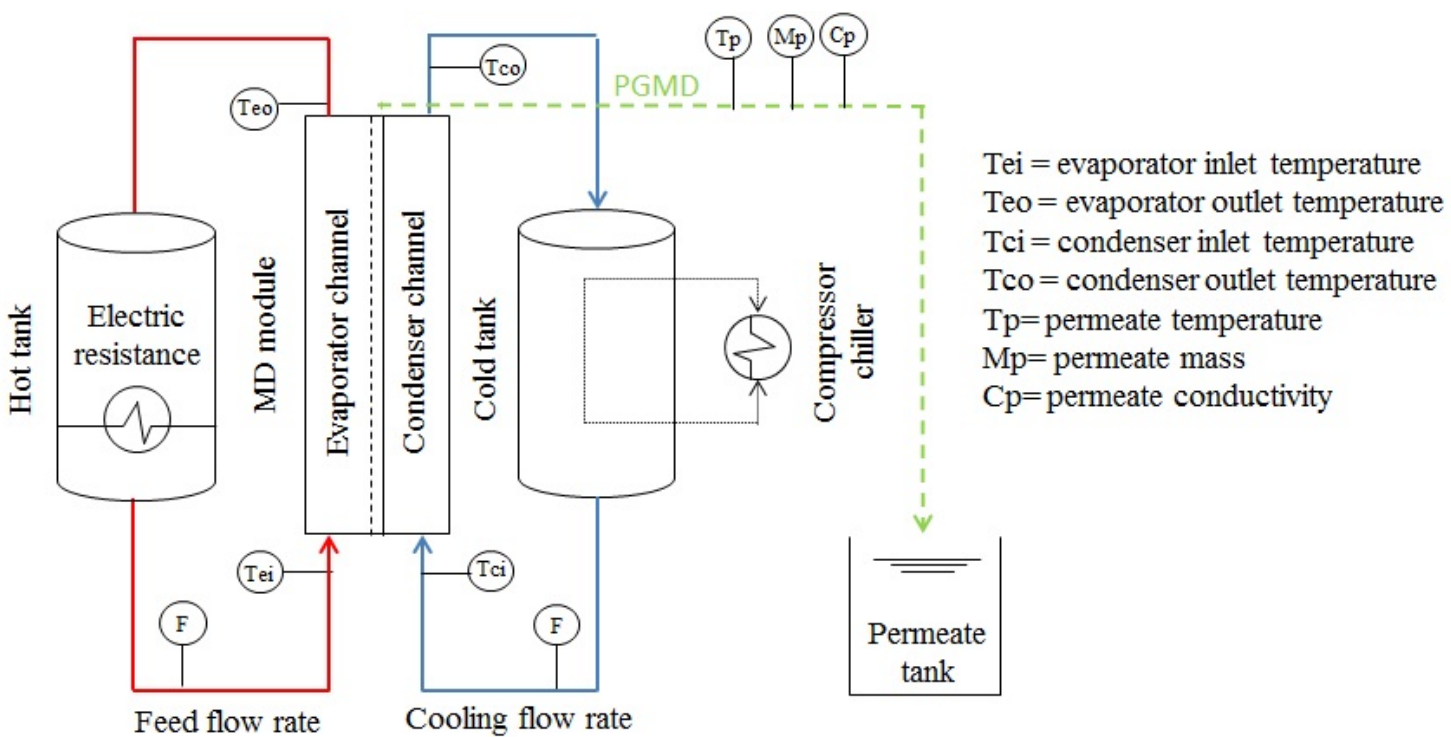

Figure 2. Hydraulic layout of the module test facility.

3

6

7

8

9

\subsection{Solar CPC photo-reactor}

The photo-Fenton process was carried out in a compound parabolic collector (CPC) reactor

(Ecosystem S.A., Environmental Services, Spain) (Figure 3) consisting of two CPC-mirror modules with a total of 20 tubes manufactured in borosilicate glass. This has been described elsewhere [28]. The CPC mirror geometry has a concentration factor of 1, it is made of MiroSun highly reflective anodized aluminium (Alanod, Germany). The total volume of the system was 601,451 of which were illuminated, corresponding to a ratio of illuminated volume to total volume of 0.75 . The flow rate used was $301 / \mathrm{min}$. Temperature (Checktemp instruments, Spain) and $\mathrm{pH}$ (Crison) values were measured directly in the $\mathrm{CPC}$ reactor during the experiments.

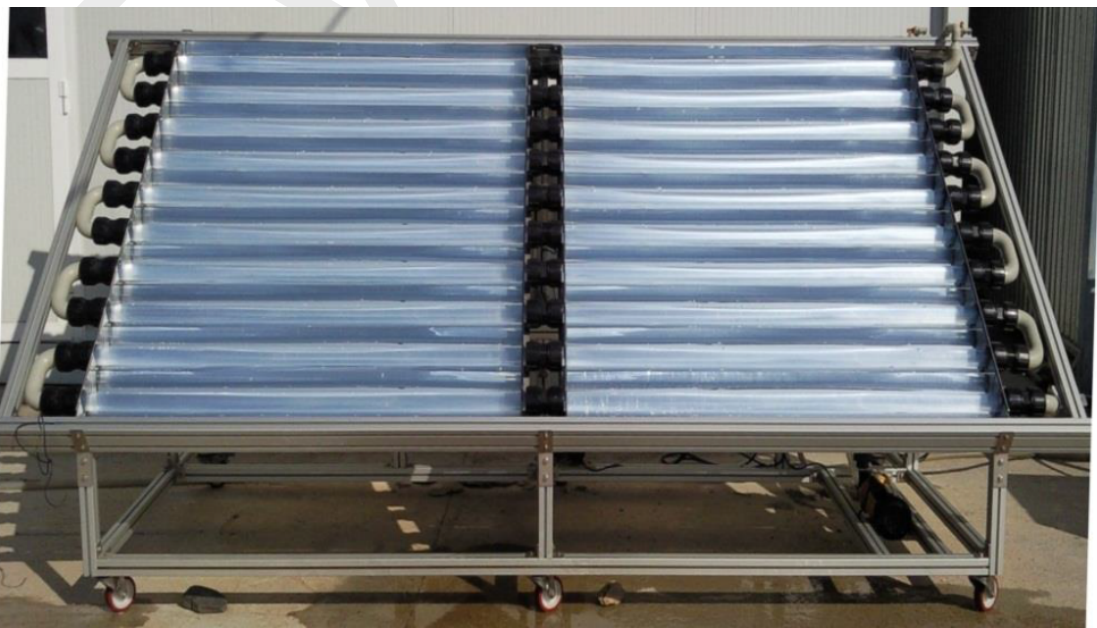

Figure 3. Solar CPC reactor used in this study.

\subsection{Solar UVA radiation}


1 Solar UVA radiation was measured by a global UV radiometer (Model CUV4, Kipp\&Zonen,

2 the Netherlands) with a typical sensitivity of $264 \mu \mathrm{V} / \mathrm{W} / \mathrm{m}^{2}$, and a central wavelength of 200-

$3400 \mathrm{~nm}$ which provides data in terms of incident $\mathrm{W}_{\mathrm{UV}} / \mathrm{m}^{2}$, placed on a platform tilted $37^{\circ}$. Q $\mathrm{UV}$

4 (eq. 3) estimates accumulated UV energy in the solar reactor per unit of treated water volume

5 for given periods of time. It allows evaluating and comparing experimental results carried out in

6 different days with different meteorological conditions.

$7 \quad Q_{U V}=\sum_{n} \overline{U V}_{n-1} \cdot \frac{A_{r}}{V_{t}} \cdot\left(t_{n}-t_{n-1}\right)$

8 Where $\mathrm{t}_{\mathrm{n}}$ is the experimental time for n-sample, $\overline{U V}_{n-1}$ is the average solar ultraviolet radiation

9 measured during the period $\left(t_{n}-t_{n-1}\right), A_{r}$ is the illuminated of reactor surface, and $V_{t}$ is the total

10 water volume. In this study, besides Quv, experimental time was used as a result too, because it

11 is important to give an idea of the effectiveness of the process and of the treatment time.

\subsection{Reagents}

Ferrous sulphate heptahydrate $\left(\mathrm{FeSO}_{4} \cdot 7 \mathrm{H}_{2} \mathrm{O}\right.$, PANREAC, Spain) was used as source of $\mathrm{Fe}^{2+}$ to obtain an initial concentration of iron of $10 \mathrm{mg} / \mathrm{l}^{-1}$. This concentration was selected based on our previous studies that evidenced the important role of light penetration in the photo-reaction and the detrimental effect of suspended precipitated iron when the added iron was higher than $10 \mathrm{mg} / \mathrm{L}[19,30]$. The concentration of $\mathrm{Fe}^{2+}$ was measured with a spectrometric method, ISO 6332. With this method is possible analyze concentrations between 0.01 and $10 \mathrm{mg} / \mathrm{l}$. The samples were filtered with NY $0.2 \mu \mathrm{m}$ CHROMAFIL ${ }^{\circledR}$ Xtra PET-20/25 (PANREAC, Spain) to remove precipitated iron. Then, $1 \mathrm{ml}$ of 1,10-phenanthroline and $1 \mathrm{ml}$ of buffer solution was added to each sample to generate an acid $\mathrm{pH}$ and to favour the formation of a colored complex between $\mathrm{Fe}^{2+}$ and 1,10-phenanthroline. Ascorbic acid is added to reduce $\mathrm{Fe}^{3+}$ in $\mathrm{Fe}^{2+}$. The coloured complex was measured with a spectrophotometer (PG Instruments Ltd T-60-U) at 510 $\mathrm{mm}$ in glass cuvettes ( $1 \mathrm{~cm}$ path length). $\mathrm{H}_{2} \mathrm{O}_{2}$ (30 wt\%, Riedel- de- Haën, Germany) was used as received to obtain a concentration of $20 \mathrm{mg} / \mathrm{l}$ in the CPC reactor. Its consumption was measured with the spectrophotometer too but with a wavelenght of $410 \mathrm{~nm}$ following DIN $38409 \mathrm{H} 15 . \mathrm{H}_{2} \mathrm{O}_{2}$ forms a yellow complex with titanium (IV) oxysulfate. Absorbance was read after 5 min incubation time against a $\mathrm{H}_{2} \mathrm{O}_{2}$ standard curve linear in the $0.1-10 \mathrm{mg} / \mathrm{l}$ concentration range. Sulphuric acid $\left(\mathrm{H}_{2} \mathrm{SO}_{4}\right.$, Merk, Germany, analytical grade) was used to obtain the required acidic conditions for photo-Fenton experiments. 
2 A series of control tests were conducted at lab-scale to find out the effect of individual

\subsection{Lab-scale experiments}

parameters including the effect of salts, temperature and acid $\mathrm{pH}$ on the viability of spores of $B$. subtilis and Clostridium sp. These tests were performed using 200-ml borosilicate glass bottles filled with synthetic salty water spiked with $B$. subtilis $\left(10^{7} \mathrm{CFU} / 100 \mathrm{ml}\right.$ initial concentration) or with real UWW containing naturally occurring Clostridium sp spores (ca. $5 \cdot 10^{3} \mathrm{CFU} / 100 \mathrm{ml}$ initial concentration). Each parameter was experimentally evaluated as follows:

i) Salt effect: Bottles with $200 \mathrm{ml}$ of marine salts $(3.5 \mathrm{wt} \%)$ sterile solution and spores of $B$. subtilis were kept under constant stirring in the dark for 5 hours.

ii) Temperature effect: Bottles with $200 \mathrm{ml}$ of sterile distilled water and spores of B. subtilis or real UWW containing Clostridium sp spores were heated up to $80{ }^{\circ} \mathrm{C}$ placing the bottles in a thermal bath in the dark for 10 hours.

iii) Acid pH effect: $\mathrm{pH} 2.8$ was set using sulphuric acid in a bottle with $200 \mathrm{ml}$ of marine salts (3.5 $\mathrm{wt} \%$ ) sterile solution spiked with spores of B. subtilis; it was kept under constant stirring in the dark for 5 hours.

In all cases, the samples were taken every hour and analyzed according to enumeration technique used for $B$. subtilis or Clostridium spores, respectively.

Finally, to test the potential detrimental effect of mechanical stress and membrane retention in $\mathrm{MD}$, an experiment was carried out in the MD test module without heating for 5 hours. In addition, the feed consisted of 801 of marine salts $(3.5 \mathrm{wt} \%)$ solution with an initial concentration of $10^{7} \mathrm{CFU} / 100 \mathrm{ml}$. Flow rates used in both sides of the membrane were the same and equal to $400 \mathrm{l} / \mathrm{h}$. Water temperature varied with ambient temperature between 20 and $30^{\circ} \mathrm{C}$. Samples were taken and analyzed every hour over 5 hours.

\subsection{MD \& solar photo-Fenton experiments}

For MD experiments, the hot tank was filled with 801 of water (salty water or UWW), and then heated up to $80^{\circ} \mathrm{C}$. The cold tank was filled with distilled water and kept at $20^{\circ} \mathrm{C}$. Once the desired temperatures were reached, B. subtilis spores were added with an initial concentration of $10^{7} \mathrm{CFU} / 100 \mathrm{ml}$ in the hot tank and the suspension was homogenized by pumping in a closed loop. When real UWW was used, there was no addition of Clostridium sp spores to the water, being the initial concentration the natural presence of this bacterium in the effluent $\left(5 \cdot 10^{4}\right.$ $\mathrm{CFU} / 100 \mathrm{ml})$. Then, the first sample $(\mathrm{t}=0 \mathrm{~min})$ was taken and the water started to pass through the evaporator channel of the MD test cell with a flow rate of $400 \mathrm{l} / \mathrm{h}$. In the other side, cooling water with a flow rate of $400 \mathrm{l} / \mathrm{h}$ started to flow too. Both fluids were recirculated continuously to their respective tanks (figure 2). These temperature and flow rate values were chosen to 
1 obtain a high permeate production in MD. Experiments were performed during 10 hours, taking

2 samples of the feed and permeate streams every hour. After MD process, the remaining feed

3 was stored in a sterilized tank for further treatment (solar photo-Fenton) the following day. For

4 photo-Fenton process, solar CPC- reactor was filled with 601 of MD feed recirculating at

$530 \mathrm{l} / \mathrm{min}$. The $\mathrm{pH}$ was adjusted closed to 3 using sulphuric acid and then iron source was added.

6 After that, the hydrogen peroxide was added and recirculated in the dark for homogenization.

7 Finally, the reactor was uncovered and an initial sample was taken, and every $30 \mathrm{~min}$

8 afterwards. All experiments started between 10:30 and 11:00 am local time and lasted $5 \mathrm{~h}$

9 exposed to sunlight; temperature and $\mathrm{pH}$ in the reactor were measured. When only photo-Fenton

10 was applied, the CPC- reactor was filled with 601 of salt water inoculated with B. subtilis spores

11 or real UWW with natural presence of Clostridium sp spores. The procedure followed was the

12 same as described above.

\section{Results and Discussion}

\subsection{B. Subtilis spores removal by MD and Photo-Fenton}

16 Prior to carrying out the experiments in MD, several tests at lab scale were performed to check

17 whether the effect of salinity, heat and mechanical stress suffered by the circulation inside the

18 MD module could mask the real effect of the MD process on the B. subtilis spores. Figure 4

19 shows the results obtained for the lab-scale experiments to test the individual effect of salts, heat

$20 \mathrm{pH}$ and mechanical stress on $B$. subtilis spores viability. Results showed that the concentration

21 of spores was constant during all time in the three bottles, evincing that they can resist a concentration of $3.5 \mathrm{wt} \%$ of marine salt, a $\mathrm{pH}$ of 2.8 and a temperature of $80{ }^{\circ} \mathrm{C}$ for 5 and 10 hours respectively. Moreover, spores did not suffer mechanical stress or adsorption on the membrane after 5 hours. 


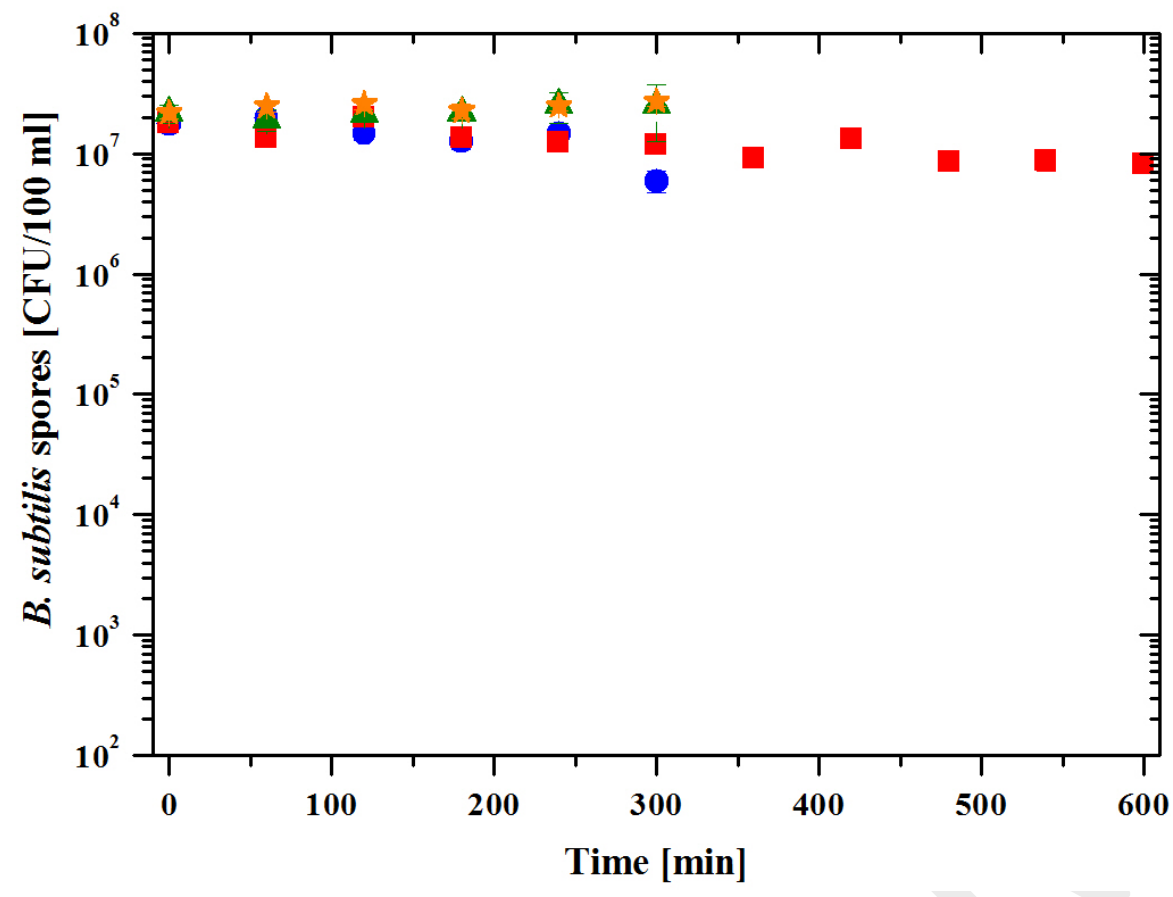

2 Figure 4. Effects of salts, heat, $\mathrm{pH}$ and mechanical stress in $B$. subtilis spores. $3.5 \mathrm{wt} \%$ salts

$$
), \mathrm{T}=80^{\circ} \mathrm{C}(\boldsymbol{\square}), \mathrm{pH}(\boldsymbol{\Delta}) \text { and mechanical stress }(\stackrel{\bar{*}}{*})
$$

4 In MD treatment of saltwater with $B$. subtilis spores, a total volume of 51 of permeate free of $B$. 5 subtilis spores was obtained (concentration below DL) with a permeate flux of $38 \mathrm{l} / \mathrm{h} . \mathrm{m}^{2}$. The 6 concentration of spores in the feed tank decreased only $1 \log$ after 10 hours of MD functioning 7 (Figure 5). This small decrease in spore concentration can be attributed to the combined effect 8 of the three stress factors occurring simultaneously (i.e. T, salt and mechanical stress) inside the 9 MD module. The following day, 601 of the remaining feed were treated in a CPC- reactor with photo-Fenton at pH 2.8 (i.e. ideal pH). Initial iron concentration added was $10 \mathrm{mg} / 1 . \mathrm{H}_{2} \mathrm{O}_{2}$ was measured and added in doses of $20 \mathrm{mg} / 1$ when the concentration was below $2 \mathrm{mg} / \mathrm{l}$ along the process as this reagent is consumed during the photo-Fenton reaction (1). A total of $80 \mathrm{mg} / \mathrm{lof}$ $\mathrm{H}_{2} \mathrm{O}_{2}$ was used in 5 hours of experiment.

14 Dissolved iron concentration was measured, and the initial concentration was much lower (2.6 $\mathrm{mg} / \mathrm{l})$ than the initially added $(10 \mathrm{mg} / \mathrm{l})$. Moreover, a variation from $2.6 \mathrm{mg} / 1$ to $0.3 \mathrm{mg} / 1 \mathrm{was}$ observed along the $5 \mathrm{~h}$ of the experiments, while $\mathrm{pH}$ remained stable at values 2.8-3.0. This is a normal behavior for Fe-complexes in water when the salinity is very high, as this case. For example, Rubio et al. [39] reported dissolved iron very close to zero during en photo-Fenton water disinfection at near neutral $\mathrm{pH}$ in artificial seawater, the authors attributed this to the $\mathrm{pH}$ and the presence of high concentrations of salts (chloride, sulphate, hydrogen carbonate). 
1 Some contributions attribute the loss of dissolved iron to the formation of iron complexes at low

$2 \mathrm{pH}(<5)$ in the presence of high concentrations of chloride ions $(>0.2 \mathrm{M})$. Ideally, in the optimal

3 conditions of photo-Fenton, at $\mathrm{pH} 2.8$, predominant iron complex is $\mathrm{Fe}(\mathrm{OH})^{2+}$, the most

4 photoactive. When $\mathrm{pH}$ increases, photoactivity of this complex decreases [22, 40]. Nevertheless,

5 other factors also influence this, as for example the presence of natural organic matter in natural

6 waters or wastewaters, and also the presence of certain concentrations of ions. This is the case

7 of seawater and brackish. Some articles have studied the influence of the high salinity in the

8 Photo-Fenton process at several $\mathrm{pH}$ values, and specifically the influence of high concentrations

9 of chloride. These articles report on the inhibition of the oxidation rate of 4-chlorophenol and

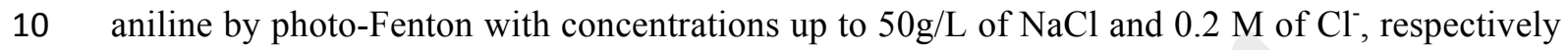

11 [41]. At high concentrations of chloride ions, the complexation of $\mathrm{Fe}-\mathrm{Cl}$ occurred (reactions 4-

12 9). This effect will decrease the iron solubility under these conditions, and it will alter the

13 generation of radicals, and therefore inhibiting the oxidation process even at low $\mathrm{pH}$ values.

14 Moreover, scavenging of hydroxyl radicals (reaction 10), will generate chloride radicals $\mathrm{Cl}^{\circ}$,

15 which are less reactive than hydroxyl radicals.

$17 \mathrm{FeCl}^{+}+\mathrm{Cl}^{-} \rightleftarrows \mathrm{FeCl}_{2}^{0}$

$$
\mathrm{Fe}^{3+}+\mathrm{Cl}^{-} \rightleftarrows \mathrm{FeCl} l^{2+}
$$

$19 \mathrm{Fe}^{3+}+2 \mathrm{Cl}^{-} \rightleftarrows \mathrm{FeCl}_{2}^{+}$

$20 * \mathrm{Fe}^{3+}(a q) \mathrm{gCl} \rightarrow \mathrm{Fe}^{2+}(a q)+\mathrm{Cl}^{\bullet}$

$21 * \mathrm{FeCl}_{3}+\mathrm{RH} \rightarrow \mathrm{FeCl}_{2}+\mathrm{HCl}+\mathrm{R}^{*}$

22 Where * symbol means that the specie is photoexcited.

Moreover, a lower inactivation in photo-Fenton in saltwater may be also due to the decrease in the transmittance of light in water with high salt concentration. $\mathrm{Cl}^{-}$and $\mathrm{SO}_{4}{ }^{2-}$ in high concentrations can absorb light and prevent microorganisms to be inactivated by direct or indirect action of photons [39].

The water temperature varied between 24 and $32{ }^{\circ} \mathrm{C}$ in the CPC reactor. This little thermal increase is the commonly observed in this type of non-concentrating solar collectors [42] which 
1 does not affect significantly the viability of spores (figure 4) but has an Arrhenius relationship 2 which explains some grade of accelerating effect on the disinfection rate of the photo-Fenton 3 [43]. The average solar UVA irradiance along the experiment was $33.9( \pm 1.2) \mathrm{W} / \mathrm{m}^{2}$, with 4 minimum and maximum values of $23.8( \pm 1.2) \mathrm{W} / \mathrm{m}^{2}$ and $38.2( \pm 1.2) \mathrm{W} / \mathrm{m}^{2}$, respectively. This corresponds to a variation of $\mathrm{Q}_{\mathrm{UV}}$ from 3.5 to $45.8 \mathrm{~kJ} / 1$. After photo-Fenton process, the spore concentration decreased from $10^{6}$ to $5 \cdot 10^{3} \mathrm{CFU} / 100 \mathrm{ml}$, therefore photo-Fenton accounted for a reduction of ca. $2.5 \operatorname{logs}$.

8 It is important to check that the reduction of the concentration of spores of B. subtilis was not due to the acid $\mathrm{pH}$ of the experiment (Figure 6). Results showed that B. subtilis spores resist perfectly the acid $\mathrm{pH}$. Therefore, acid $\mathrm{pH}$ did not affect the concentration of spores.

To find out the effect of photo-Fenton without prior MD treatment, another experiment was carried out. In this case, the contaminated solution had initial concentration of $10^{6} \mathrm{CFU} / 100 \mathrm{ml}$ to reproduce the concentration as when photo-Fenton was used after MD treatment. The experiment required a total adding of $10 \mathrm{mg} / \mathrm{l} \mathrm{of} \mathrm{Fe}^{2+}$ and $100 \mathrm{mg} / 1$ of $\mathrm{H}_{2} \mathrm{O}_{2}$ in doses of $20 \mathrm{mg} / \mathrm{l}$, in spite of that, no reduction of spores at all during the $5 \mathrm{~h}$ of experiment was observed. Water temperature varied between 27 and $35{ }^{\circ} \mathrm{C}$. The average solar UVA irradiance during all the experiment was $35.1( \pm 1.2) \mathrm{W} / \mathrm{m}^{2}$, with minimum and maximum values of $20.1(+1.2) \mathrm{W} / \mathrm{m}^{2}$ and $43.1(+1.2) \mathrm{W} / \mathrm{m}^{2}$, respectively. This corresponds to a variation of Quv from 3.7 to $47.3 \mathrm{~kJ} / \mathrm{l}$. Results showed the concentration of B. subtilis spores was kept totally constant and equal to $10^{6} \mathrm{CFU} / 100 \mathrm{ml}$, which clearly indicates that $B$. subtilis is completely resistant to photo-Fenton in acidic conditions. Bandala et al [44] achieved the inactivation of B. subtilis spores using photo-Fenton process. However, the amount of iron and $\mathrm{H}_{2} \mathrm{O}_{2}$ used for only $25 \mathrm{ml}$ of solution was very high (initial concentration of iron and $\mathrm{H}_{2} \mathrm{O}_{2}$ was $2.5 \mathrm{mM}$ and $100 \mathrm{Mm}$ respectively) compared to this study (only $0.036 \mathrm{mM}$ and $0.588 \mathrm{mM}$ of iron and $\mathrm{H}_{2} \mathrm{O}_{2}$ were added to $60 \mathrm{l}$ of contaminated solution).

Thus, it can be concluded that the treatment of contaminated water with B. subtilis spores with MD resulted very satisfactory for two reasons. On one hand, a permeate totally free of spores was produced, and on the other hand, MD favoured the 2.5-log reduction of B. subtilis spore concentration when photo-Fenton was used, while photo-Fenton without a previous MD process did not achieve any significant reduction of spores in the same time of operation with the same amount of solar radiation and using a similar amount of reagents. This difference can be attributed to the heating effect suffered by the spores during the MD process, which although is not enough to significantly kill all the spores, it may generate a sub-lethal effect that produce a 
1 Therefore, the combination of these technologies represents clear advantages for inactivation of

2 highly resistant waterborne pathogens.

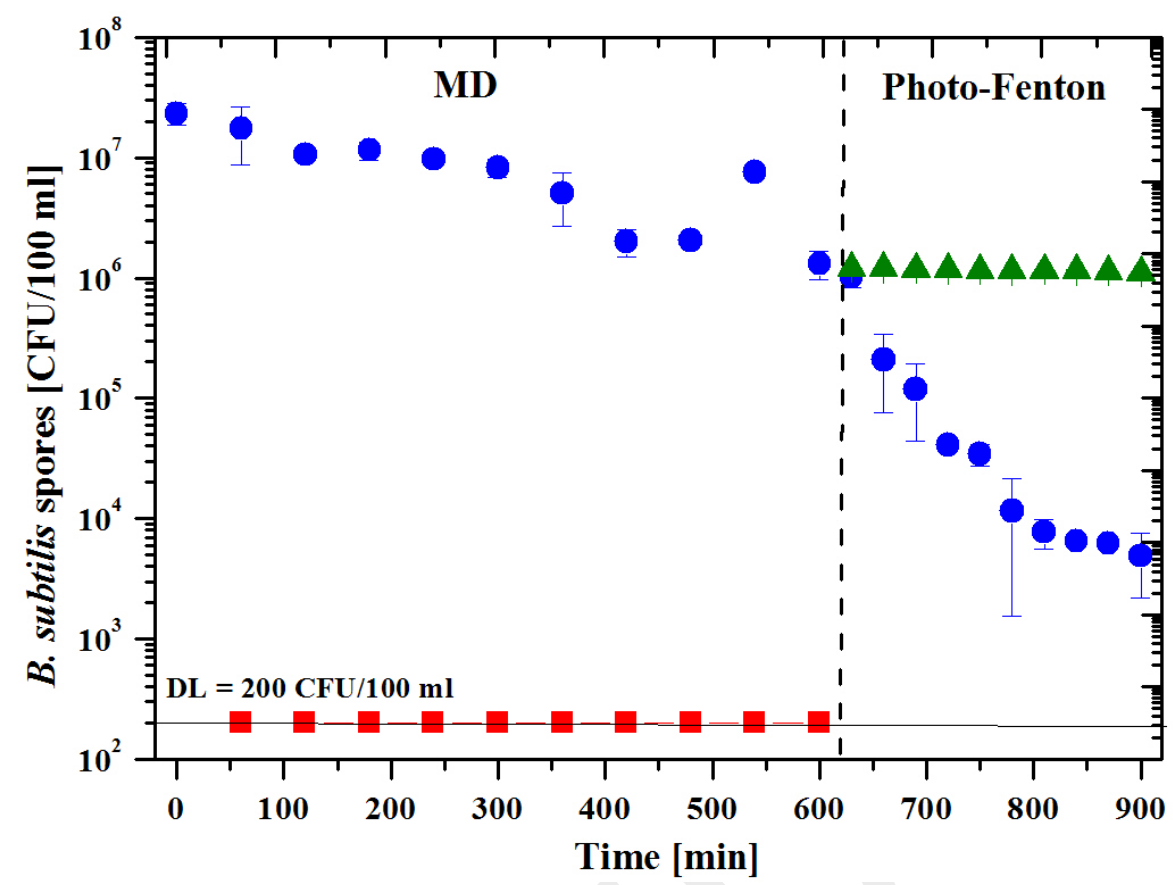

Figure 5. Evolution of B. subtilis spores concentration after MD and photo-Fenton treatments. Feed (MD + photo-Fenton) $(\bullet)$, red square: permeate from MD ( $\square)$, Feed (only photo-Fenton) $(\mathbf{4})$

\subsection{Clostridium sp spores elimination by MD and photo-Fenton processes.}

UWW containing Clostridium sp spores $\left(5 \cdot 10^{3} \mathrm{CFU} / 100 \mathrm{ml}\right)$ was treated by MD over 10 hours. A total volume of 4.41 of permeate free of Clostridium sp spores was obtained. This corresponds to a permeate flux of $34 \mathrm{l} / \mathrm{h} \cdot \mathrm{m}^{2}$. Spore concentration in the feed tank decreased to below $10^{2} \mathrm{CFU} / 100 \mathrm{ml}$ (Figure 6). To check whether this reduction was due to the effect of the thermal stress, a lab-scale experiment was performed. Figure 7 shows that Clostridium sp spores can resist $80^{\circ} \mathrm{C}$ for 4 hours but from this time the concentration decreased $1.5 \log$. This decrease was observed after $4 \mathrm{~h}$, similar to the time (after $5 \mathrm{~h}$ ) that spores concentration was reduced in the MD module. Therefore, this indicates that the principle responsible for the reduction of the concentration of the spores was the heat supplied in the MD process. The following day, 601 of the MD feed were treated by photo-Fenton at $\mathrm{pH}=2.8$ (Fe at $10 \mathrm{mg} / \mathrm{l}$, $\mathrm{H}_{2} \mathrm{O}_{2}$ at $20 \mathrm{mg} / \mathrm{l}$ ) in solar CPC reactor. Since $\mathrm{H}_{2} \mathrm{O}_{2}$ was consumed along the experiment, it was added four times to maintain $20 \mathrm{mg} / \mathrm{l}$ of the oxidant, making a total of $100 \mathrm{mg} / 1$ of $\mathrm{H}_{2} \mathrm{O}_{2}$ added for 5 hours of operation. A variation of the initial dissolved iron concentration from 4.65 to 3.65 $\mathrm{mg} / \mathrm{l}$ was observed along the $5 \mathrm{~h}$ of experiment. The possible causes of this reduction have been 
1 widely discussed in the previous section. The temperature varied between 35 and $45{ }^{\circ} \mathrm{C}$ in the

2 solar reactor. The average solar UVA irradiance during all the experiment was $33.0( \pm 1.2)$

$3 \mathrm{~W} / \mathrm{m}^{2}$, with minimum and maximum values of $23.7( \pm 1.2) \mathrm{W} / \mathrm{m}^{2}$ and $36.9( \pm 1.2) \mathrm{W} / \mathrm{m}^{2}$,

4 respectively. This corresponds to a variation of Q $\mathrm{Uv}$ from 3.4 to $44.6 \mathrm{~kJ} / 1$. After $2.5 \mathrm{~h}$ of photo-

5 Fenton process, the spore concentration depleted completely, below the DL of 2 CFU/100 ml

6 (Figure 6). Therefore the combination of MD and photo-Fenton processes achieved the total

7 elimination of Clostridium sp spores in UWW. Another control photo-Fenton test at $\mathrm{pH}=2.8$

8 without prior MD was carried out with Clostridium sp spores (Figure 7, green triangle

9 symbols). The proportion of the iron: $\mathrm{H}_{2} \mathrm{O}_{2}$ was the same as previous experiments, adding doses

10 of $\mathrm{H}_{2} \mathrm{O}_{2}$ when the concentration was below $2 \mathrm{mg} / \mathrm{l}$. The temperature varied from 30 to $37.5^{\circ} \mathrm{C}$.

11 The average solar UVA irradiance during all the experiment was $35.5(+1.2) \mathrm{W} / \mathrm{m}^{2}$, with

12 minimum and maximum values of $28.7( \pm 1.2) \mathrm{W} / \mathrm{m}^{2}$ and $39.2(+1.2) \mathrm{W} / \mathrm{m}^{2}$, respectively. This

13 corresponds to a variation of $\mathrm{Q}_{\mathrm{UV}}$ from 4.1 to $38.4 \mathrm{~kJ} / 1$. A reduction of something more than 1

$14 \log$ (from $2 \times 10^{3}$ to $10^{2} \mathrm{CFU} / 100 \mathrm{ml}$ ) after $4 \mathrm{~h}$ was observed. The reduction rate when only

15 photo-Fenton was used was lower than that when MD was used as a pretreatment. It seems like

16 the thermal stress suffered at the MD treatment favoured the reduction of spores in the photo-

17 Fenton process afterwards. For this reason, it was concluded that the combination of MD and

18 photo-Fenton process resulted beneficial for the removal of Clostridium sp spores, achieving

19 full elimination in only 2.5 hours of solar photo-Fenton.

20 Clostridium sp in real wastewater effluents, as indicator of Giardia sp and Cryptosporidium sp,

21 is recognized as a very resistant model pathogen that cannot be easily inactivated by standard

22 tertiaty treatments, i.e. UV and UV followed by chlorine [45, 46], by mixed oxidant

23 disinfectants and chlorine [33], or even by solar AOPs. Specifically, Agulló et al [37] studied

24 the inactivation of SRC oocysts by $\mathrm{H}_{2} \mathrm{O}_{2}, \mathrm{TiO}_{2}$ and photo-Fenton process under natural solar radiation. In all the cases, SRC oocysts showed a slow sensitivity against different treatments studied. In this work, we demonstrated that the combination of two solar driven processes accelerates the disinfection of real wastewater effluents containing Clostridium spores. There are no other results of this pathogen in the literature. This has clear implications in the use of solar membrane distillation for water purification when applied to real wastewater, as it produces a high quality clean permeate, and the concentrate can be successfully disinfected by solar photo-Fenton. 


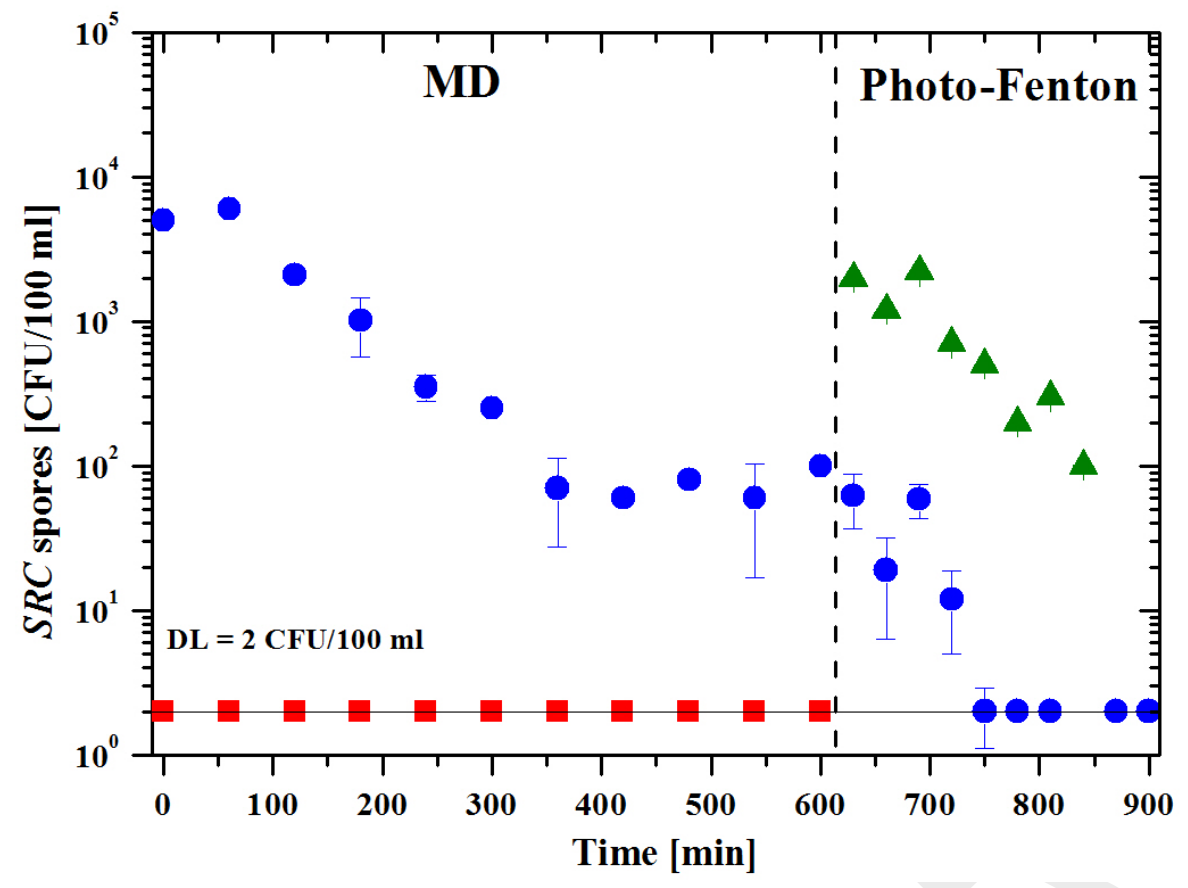

Figure 6. Evolution of $S R C$ spores concentration after $\mathrm{MD}$ and photo-Fenton treatments. Feed $(\mathrm{MD}+$ photo-Fenton) $(\bullet)$, permeate from MD $(\boldsymbol{\square})$, Feed (only photo-Fenton) $(\mathbf{4})$.

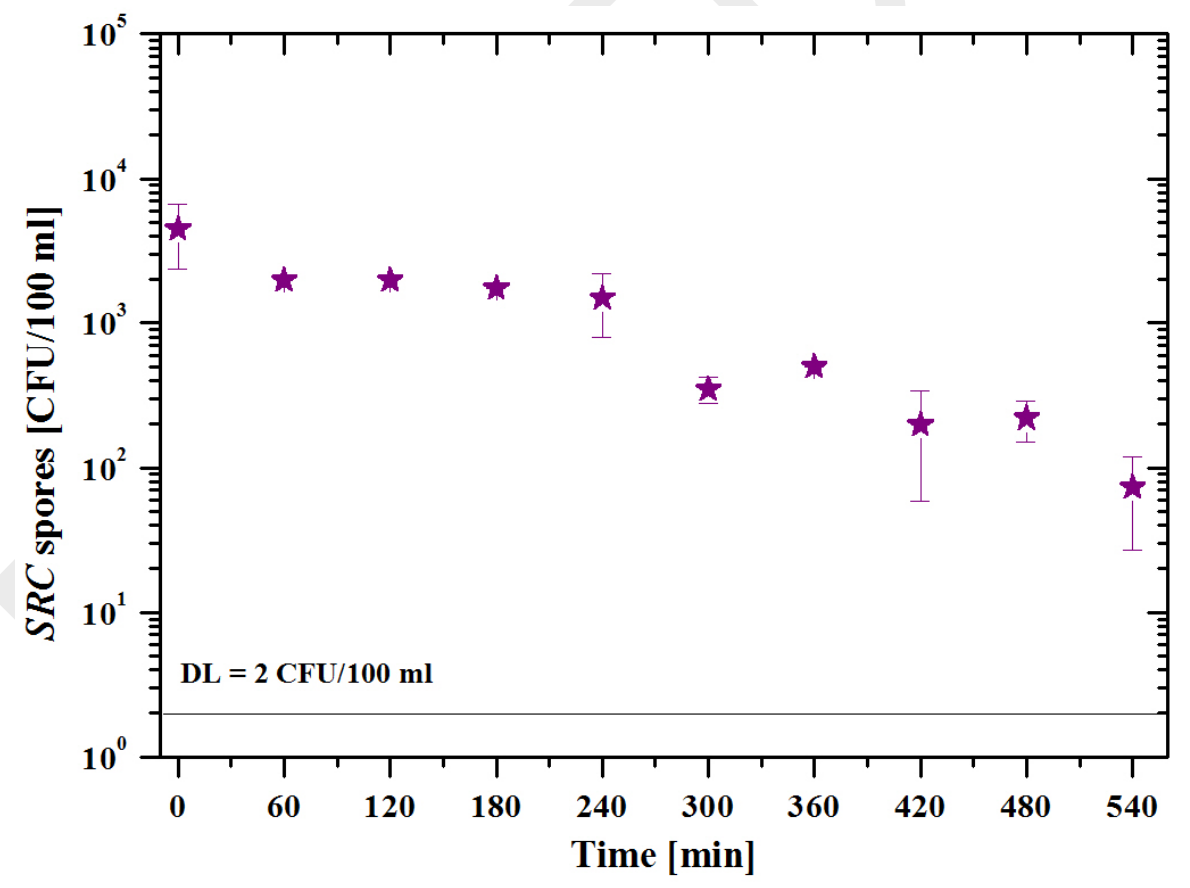

Figure 7. Effects of heat in $S R C$ spores. $\mathrm{T}=80^{\circ} \mathrm{C}$.

6

\section{Conclusions}

8 This study contributed to establish an alternative process for the elimination of highly resistant 9 spores, specifically B. subtilis and Clostridium spores, from wastewater towards its use in 
1 agriculture. The proposed mechanism was MD process. For both cases, MD was satisfactory in 2 obtaining a permeate totally free of spores. Therefore, MD can be used to obtain an effluent free

3 of spores that can be discharged into rivers or reused in the field of agriculture. Moreover, the 4 effect of MD as a pretreatment of a tertiary treatment like photo-Fenton was also proven. For 5 both pathogens $B$. subtilis and Clostridium spores, the photo-Fenton process did not affect the 6 concentration of spores while the combination of MD and photo-Fenton process achieved a significant reduction. These are important results because these spores are very resistant to a wide variety of tertiary treatments and the proposed treatment here can be a solution for the removal of highly resistant endospores. Moreover, it is expected that if the combination of MD and photo-Fenton is capable of reducing B. subtilis and Clostridium spores, it could be able to eliminate other less resistant pathogens under the same conditions.

\section{Acknowledgements}

The authors wish to thank the financial support given by the European Commission under the Switch-Asia project Zero Carbon Resorts (reference: DCI-ASIE/2013/334140), and the Spanish Ministry of Economy and Competitiveness through the collaborative WATER4FOOD project (CTQ2014-54563-C3).

\section{References}

[1] Human Development Report 2006, UNDP, 2006.

[2] W. Jusi, Water shortage and wastewater reuse, Journal of Environmental Sciences 2 (3) (1990) 67-78.

[3] A. Pollice, A. Lopez, G. Laera, P. Rubino, A. Lonigro, Tertiary filtered municipal wastewater as alternative water source in agriculture: a field investigation in Southern Italy, Science of The Total Environment 324:1-3 (2004) 201-210. pollutants and pathogens by a simplified treatment scheme for municipal wastewater reuse in agriculture, Science of The Total Environment 580 (2017) 17-25. 1800-2010, Science of The Total Environment 572 (2016) 1471-1484. 
1 [6] M.B. Pescod, Wastewater treatment and use in agriculture, Bull FAO, 47, Rome, 1992

2 [7] D. Fatta-Kassinos, I.K. Kalavrouziotis, P.H. Koukoulakis, M.I. Vasquez, The risks 3 associated with wastewater reuse and xenobiotics in the agroecological environment, Science of 4 The Total Environment, 409:19 (2011) 3555-3563.

5 [8] Gyan Chhipi-Shrestha, Kasun Hewage, Rehan Sadiq, Microbial quality of reclaimed water 6 for urban reuses: Probabilistic risk-based investigation and recommendations, Science of The 7 Total Environment 576 (2017) 738-751.

8 [9] S. Toze, Reuse of effluent water-benefits and risks, Agricultural Water Management 80 9 (2006) 147-159.

10 [10] M. De Sanctis, G. Del Moro, C. Levantesi, M. L. Luprano, C. Di Iaconi, Integration of an 11 innovative biological treatment with physical or chemical disinfection for wastewater reuse, 12 Science of The Total Environmental 543 (2016) 206-213.

[11] L. Rizzo, A. D. Nikolaou, P. Andrzejewski, Chlorination In: Control of Disinfection By14 Products in Drinking Water Systems. Eds.: A. Nikolau, Luigi Rizzo and H. Selcuk, pp 3-28, 15 Nova Science Publishers, Inc. 2007.

[12] S. Malato, P. Fernández-Ibáñez, M. I. Maldonado, J. Blanco, W. Gernjak, Decontamination and disinfection of water by solar photocatalysis: recent overview and trends, Catalysis Today 147 (2009) 1-59.

[13] Y. Luo, W. Guo, H. H. Ngo, L. D. Nghiem, F. I. Hai, J. Zhang, S. Liang, X. C. Wang, A review on the occurrence of micropollutants in the aquatic environment and their fate and removal during wastewater treatment, Science of the Total Environment 473-474 (2014) 619641.

[14] N. Klamerth, S. Malato, A. Agüera, A. R. Fernández-Alba, Photo-Fenton and modified photo-Fenton at neutral $\mathrm{pH}$ for the treatment of emerging contaminants in wastewater treatment plant effluents: a comparison, Water Research 47 (2013) 833-840.

[15] I. B. S. Will, J. E. F. Moraes, A. C. S. C. Teixeira, R. Guardani, C. A. O. Nascimento, Photo-Fenton degradation of wastewater containing organic compounds in solar reactors, Separation and Purification Technology 34 (2004) 51-57. concentration for solar disinfection of distilled water. A case study: Phytophthora capsici, Catalysis Today 209 (2013) 181-187. 
1 [17] G. Ferro, A. Fiorentino, M. Castro-Alférez, M. I. Polo-López, L. Rizzo, P. Fernández-

2 Ibáñez, Urban Wastewater disinfection for agricultural reuse: effect of solar driven AOPs in the

3 inactivation of a multidrug resistant E. coli strain, Applied Catalysis B: Environmental 178

$4 \quad$ (2015) 65-73.

5 [18] J. Rodríguez-Chueca, M. P. Ormad, R. Mosteo, J. L. Ovelleiro, Conventional and 6 Advanced Oxidation Processes used in disinfection of treated Urban Wastewater, Water 7 Environmental Research 87 (2015) 281-288.

8 [19] J. Rodríguez-Chueca, M. I. Polo-López, R. Mosteo, P. Fernández-Ibañez, Disinfection of 9 real and simulated urban wastewater effluents using a mild solar photo-Fenton, Applied 10 Catalysis B Environmetal 150 (2014) 619-629.

11 [20] S. Giannakis, M. I. Polo-López, D. Spuhler, J. A. Sánchez-Pérez, P. Fernández-Ibáñez, C. 12 Pulgarin, Solar disinfection is an augmentable, in situ-generated photo-Fenton reaction-Part 2: 13 A review of the applications for drinking water and wastewater disinfection, Applied Catalysis 14 B: Environmental 199 (2016) 431-446.

15 [21] L. Rizzo, C. Manaia, C. Merlin, T. Schwartz, C. Dagot, M. C. Ploy, I. Michael, D. Fatta16 Kassinos, Urban wastewater treatment plants as hotspots for antibiotic resistant bacteria and genes spread into the environment : A review, Science of the Total Environment 447 (2013) 345-360.

[22] J. J. Pignatello, E. Oliveros, A. Mackay, Advanced oxidation processes for organic contaminant destruction based on the Fenton reaction and related chemistry, Critical Reviews in Environmental Science and Technology 36 (2006) 1-84.

[23] A. Ruiz-Aguirre, D. C. Alarcón-Padilla, G. Zaragoza, Productivity analysis of two spiralwound membrane distillation prototypes coupled with solar energy, Desalination and Water treatment 55 (2015) 2777-2785.

[24] I. Hitsov, T. Maere, K. De Sitter, C. Dotremont, I. Nopens, Modelling approaches in membrane distillation: A critical review, Separation and Purification Technology 142 (2015) $48-64$.

[25] M. M. Teoh, T-S. Chung, Membrane distillation with hydrophobic macrovoid-free PVDFPTFE hollow fiber membranes, Separation and Purification Technology 66 (2009) 229-236. water from saline water, Journal of Novel Applied Sciences (2013) 1072-1075. 
1 [27] E. Curcio, E. Drioli, Membrane distillation and related operations- A review, Separation \&

2 Purification Reviews 34 (2005) 35-86.

3 [28] A. Ruiz-Aguirre, M. I. Polo-López, P. Fernández-Ibáñez, G. Zaragoza, Assessing the 4 validity of solar membrane distillation for disinfection of contaminated water, Desalination and $5 \quad$ Water Treatment 55 (10) (2015) 2792-2799.

6 [29] D.A. Mossel, C.B. Struijk, Escherichia coli, other Enterobacteriaceae and additional 7 indicators as markers of microbiologic quality of food: Advantages and limitations, 8 Microbiologia SEM 11 (1995) 75-90.

9 [30] I. García-Fernández, M.I. Polo-López, I. Oller, P. Fernández-Ibáñez, Bacteria and fungi inactivation using $\mathrm{Fe}^{3+}$ /sunlight, $\mathrm{H}_{2} \mathrm{O}_{2}$ /sunlight and near neutral photo-Fenton: A comparative study, Applied Catalysis B: Environmental 121-122 (2012) 20-29.

[31] P. Setlow. 2014. Spore resistance properties. In Driks A, Eichenberger P (ed), The Bacterial Spore: from Molecules to Systems. ASM Press, Washington, DC. p. 201-215. 2016.

[32] P. Zhang, L. Kong, P. Setlow, Y.G. Li, Characterization of wet-heat inactivation of single spores of Bacillus species by dual-trap raman spectroscopy and elastic light scattering, Applied and Environmental Microbiology 76(6)(2010)1796-1805.

[33] L. V. Venczel, M. Arrowood, M. Hurd, M. D. Sobsey, Inactivation of Cryptosporidium parvum oocysts and Clostridium perfringens spores by a mixed-oxidant disinfectant and by free chlorine, Applied and Environmental Microbiology 63(4) (1997) 1598-1601.

[34] P. Setlow, Spores of Bacillus subtilis: their resistance to and killing by radiation, heat and chemicals, Journal of Applied Microbiology 101 (2006) 514-525.

[35] D. L. Popham, S. Sengupta, P. Setlow, Heat, hydrogen peroxide, and UV resistance of Bacillus subtilis spores with increased core water content and with or withput major DNABinding proteins, Applied and Environmental Microbiology 61 (1995) 3633-3638. [36] A. Driedger, E. Staub, U. Pinkernell, B. Mariñas, W. Köster, U. V. Gunten, Inactivation of 27 B. subtilis spores and formation of bromate during ozonation, Water Research 35 (2001) 29502960.

[37] M. Agulló-Barceló, M.I. Polo-López, F. Lucena, J. Jofre and P. Fernández-Ibáñez, Solar Advanced Oxidation Processes as disinfection tertiary treatments for real wastewater: implications for water reclamation, Applied Catalysis B: Environmental 136-137 (2013) 341350. 
1 [38] E. P. Ivanova et al, Characterization of Bacillus strains of marine origin, International

2 Microbiology 2 (1999) 267-271.

3 [39] D. Rubio, E. Nebot, J.F. Casanueva, C. Pulgarin, Comparative effect of simulated solar 4 light, $\mathrm{UV}, \mathrm{UV} / \mathrm{H}_{2} \mathrm{O}_{2}$ and photo-Fenton treatment $\left(\mathrm{UVeVis} / \mathrm{H}_{2} \mathrm{O}_{2} / \mathrm{Fe}^{2+, 3+}\right.$ ) in the Escherichia coli 5 inactivation in artificial seawater, Water Research 47 (2013) 6367-6379.

6 [40] S. J. Hug, O. Leupin, Iron-catalyzed oxidation of arsenic (III) by oxygen and by hydrogen 7 peroxide: $\mathrm{pH}$-dependent formation of oxidants in the Fenton reaction, Environmental Science \& 8 Technology 37 (12) (2003) 2734-2742.

9 [41] M. C. Lu, Y. F. Chang, I. M. Chen, Y. Y. Huang, Effect of chloride ions on the oxidation 10 of aniline by Fenton's reagent, Journal of Environmental Management 75 (2005) 177-182.

11 [42] I García-Fernández, I Fernández-Calderero, M. I. Polo-López, P Fernández-Ibáñez, 12 Disinfection of urban effluents using solar $\mathrm{TiO}_{2}$ photocatalysis: A study of significance of 13 dissolved oxygen, temperature, type of microorganism and water matrix, Catalysis Today 240 14 (2015) 30-38.

15 [43] J. Farias, E. D. Albizzati, O. M. Alfano, Kinetic study of the photo-Fenton degradation of 16 formic acid. Combined effects of temperature and iron concentration, Catalysis Today 144 17 (2009) 117-123.

18 [44] E. R. Bandala, R. Pérez, A. E. V. Lee, J. L. Sánchez-Salas, M. A. Quiroz, M. A. Méndez19 Rojas, Bacillus subtilis spore inactivation in water using photo-assisted Fenton reaction, 20 Sustainable Environment Research 21 (2011) 285-290.

21 [45] A. M. Nasser, N. L. Benisti, N. Ofer, S. Hovers, Y. Nitzan, Comparative reduction of 22 Giardia cysts, F+ coliphages, sulphite reducing clostridia and fecal coliforms by wastewater treatment processes, Journal of Environmental Science and Health 52 (2) (2017) 144-148.

24 [46] M. E. Rubiano, M. Agulló-Barceló. R. Casas-Mangas, J. Jofre, F. Lucena, Assessing the effects of tertiary treated wastewater reuse on a Mediterranean river (Llobregat, NE Spain), part 26 III: pathogens and indicators, Environmental Science and Pollution Research 19 (2012) 10261032. 